\title{
PENGARUH TERPAAN IKLAN LAYANAN MASYARAKAT, PENGGUNAAN MEDIA SOSIAL FACEBOOK, DUKUNGAN KELUARGA, DUKUNGAN LINGKUNGAN KERJA TERHADAP TINGKAT KEBERHASILAN IBU BEKERJA MEMBERI ASI EKSKLUSIF
}

\author{
Andra Fatma Kurniasari
}

\begin{abstract}
This study examine exposure of public service announcements, facebook, family support, and company support which is involving working mom to have exclusive breastfeeding. Thecoefficient determination of this study is 70,2. It shows that all of variables affect the successfully working mom giving exclusive breastfeeding. This study also verified the Social Learning Theory, Social Marketing concept, Dynamic Social Impact Theory, and Social Support Theory.
\end{abstract}

Keywords: Working Mom, Exclusive Breastfeeding, Exposure Public Service Announcements

\section{Pendahuluan}

Air Susu Ibu (ASI) merupakan makanan paling alami yang diciptakan Tuhan untuk bayi yang baru saja dilahirkan. Kandungan nutrisi dalam ASI tidak dapat tergantikanoleh makanan dan minuman apapun yang ada di dunia ini. Semua nutrisi yang dibutuhkan untuk tumbuh kembang bayi ada dalam ASI. Demikian pentingnya ASI mendasari United Nation Childrens Fund (UNICEF) dan World Health Organization (WHO) merekomendasikan sebaiknya anak hanya disusui Air Susu Ibu atau ASI Eksklusif selama paling sedikit 6 bulan.

Sejalan dengan yang direkomendasikan WHO, Pemerintah Indonesia mengatur mengenai pemberian ASI eksklusif antara lain dalam Undang-Undang No. 36 tahun 2009 tentang Kesehatan, pada pasal 128 disebutkan bahwa Setiap bayi yang lahir berhak untuk mendapatkan ASI eksklusif. Hak bayi juga dicantumkan dan Peraturan Pemerintah no. 33 tahun 2012, dalam pasal 6 disebutkan : "Bayi berhak mendapatkan ASI eksklusif sejak lahir sampai berumur 6 bulan”. Pasal ini dikuatkan lagi oleh pasal selanjutnya, pasal 7 menyebutkan : "Kemungkinan bayi tidak bisa mendapat haknya adalah : (1) indikasi medis, (2) ibu tidak ada (meninggal), (3) ibu dan anak terpisah (tidak diketahui keberadaannya, bencana)".

Meskipun pemerintah telah ikut andil dalam memaksimalkan pemberian ASI eksklusif, namun pada kenyataannya cakupan pemberian ASI eksklusif belum dapat mencapai target yang diharapkan. Berdasarkan data yang dipublikasikan Pusat Data dan Informasi Kementrian Kesehatan Republik Indonesia disebutkan bahwa cakupan pemberian ASI eksklusif bayi 0-6 bulan di Indonesia angkanya fluktuatif. Hasil Survei Demografi dan Kesehatan Indonesia tahun 2007 menunjukkan cakupan ASI eksklusif bayi 0-6 bulan adalah 32\% dimana terlihat kenaikan yang cukup signifikan pada tahun 2012 menjadi 42\% (Infodatin, 2012: 3). 
Cakupan ASI eksklusif secara nasional kembali naik pada tahun 2014, yaitu sebesar 52,3\%. Meski menunjukkan kenaikan yang cukup signifikan, namun angka tersebut masih sangat jauh dari target yang ditetapkan oleh Kementrian Kesehatan RI yaitu 80\% pada tahun 2015 (Profil kesehatan Indonesia, 2014: 114).

Belum tercapainya target nasional ibu menyusui dipengaruhi oleh beberapa faktor antara lain: (1) pemasaran susu formula yang semakin gencar, (2) ibu kembali bekerja, (3) perusahaan tidak memberi kesempatan bagi wanita untuk memberi ASI eksklusif, (4) Belum maksimalnya kegiatan edukasi, sosialisasi, advokasi, dan kampanye terkait pemberian ASI.

Salah satu upaya sosialisasi yang dilakukan pemerintah melalui Kementrian Kesehatan Republik Indonesia adalah menayangkan Iklan Layanan Masyarakat (ILM). Dalam satu tahun belakangan sering muncul iklan mengenai ASI eksklusif, salah satunya adalah versi "Ruang ASI". Pesan yang berusaha disampaikan oleh Kementrian Kesehatan RI melalui ILM ini adalah bahwa ibu bekerja tetap bisa memberikan ASI eksklusif. Ibu dapat memerah ASI disela waktu bekerja di kantor, kemudian disimpan di almari pendingin yang disediakan oleh perusahaan di "Ruang ASI". Ibu yang memberi ASI eksklusif produktivitas kerjanya dapat terjaga, karena bayi lebih sehat, jarang sakit, ibu jarang absen.

Iklan merupakan salah satu bentuk komunikasi persuasif yang berupaya membujuk target audiens agar mau membeli barang atau jasa yang ditawarkan. Sedangkan iklan layanan masyarakat sedikit berbeda dengan iklan komersil, ILM merupakan salah satu bagian dari social marketing, memuat strategi komunikasi persuasif yang memiliki tujuan untuk merubah perilaku agar sesuai dengan apa yang dianggap baik di dalam masyarakat (Peter \& Olson, 1999: 209).

Masyarakat saat ini tidak hanya diterpa informasi melalui media televisi, koran, radio saja. Perkembangan media baru yang berbasis pada internet telah sangat memengaruhi pola konsumsi media pada masyarakat Indonesia. Ledakan pengguna internet sebagai "ruang" untuk membangun relationship dapat dilihat berdasarkan jumlah pengguna internet di Asia pada akhir tahun 2013. Indonesia masuk dalam top 5 besar pengguna internet di Asia dengan jumlah 71,2 juta usersdibawah China, India, Jepang, dan diatas Korea Selatan.

Facebook merupakan media sosial yang paling sering diakses oleh pengguna internet. Penggunaan facebook bisa disadari motif untuk bersosialisasi, mencari informasi, bahkan sebagai media promosi ataupun pemasaran. Sebagai media informasi, pengguna facebook biasanya saling sharelink ataupun share pengetahuan dan pengalaman yang bisa dijadikan rujukan bagi pengguna lain. Demikian juga yang dilakukan oleh ibu yang memiliki bayi, biasanya mereka akan mencari informasi tentang ASI eksklusif, bersosialisasi dengan sesama ibu yang memiliki bayi, share pengalaman menyusui. Bagi ibu muda yang baru saja memiliki bayi bergabung dengan komunitas ibu menyusui di facebook juga menjadi pilihan untuk memperkaya pengetahuan seputar menyusui. Komunitas AIMI dan Exclusive Pumping Mama Indonesia merupakan komunitas yang besar dan memiliki banyak member atau anggota.

Bagi ibu menyusui terutama ibu yang bekerja, dukungan dari keluarga sangat dibutuhkan. Meninggalkan anak untuk bekerja merupakan pilihan berat bagi setiap ibu baru. Jika keinginan ibu untuk tetap memberi ASI eksklusif tidak didukung, bukan tidak mungkin ibu akan beralih pada susu formula. 
Apalagi jika saran untuk memberikan susu formula datangnya dari suami, orang tua, atau mertua, ibu akan lebih mudah terpengaruh. Terlebih jika bayi dititipkan pada orang tua atau pada mertua yang tidak memiliki informasi pentingnya ASI eksklusif. Mereka yang tidak meu direpotkan dengan tata cara pemberian ASI perah akan dengan mudah menyarankan untuk beralih pada susu formula.

Dalam penelitian sebelumnya, ditemukan faktor-faktor yang menghambat keberhasilan menyusui pada ibu bekerja adalah pendeknya waktu cuti kerja, kurangnya dukungan tempat kerja, pendeknya waktu istirahat saat bekerja (tidak cukup untuk memerah ASI), tidak adanya ruangan untuk memerah ASI, pertentangan keinginan ibu antara mempertahankan prestasi kerja dan produksi ASI (Wilar, 2010: 32). Temuan penelitian-penelitian inilah yang mungkin mendasari pemerintah menerbitkan Peraturan Pemerintah No. 33 tahun 2012 tentang Pemberian Air Susu Ibu Eksklusif pasal 30 yang mengharuskan perusahaan atau instansi yang mempekerjakan wanita untuk mendukung pemberian ASI eksklusif. Oleh karena itu, peneliti tartarik mencari berapa besar pengaruh dukungan lingkungan kerja terhadap tingkat keberhasilan ibu bekerja memberi ASI eksklusif khususnya di Kota Semarang.

\section{Kerangka Teori}

Penelitian ini menggunakan teori yang masuk dalam tradisi sosiopsikologis, yang memandang individu sebagai bagian dari sebuah komunitas manusia dan terikat oleh interaksi sosial. Studi individu sebagai makhluk sosial, merupakan tujuan dari tradisi sosiopsikologis (sociopsychological). Teori ini berfokus pada perilaku sosial individu, variabel psikologis, efek individu, kepribadian, sifat, persepsi, serta kognisi. Meskipun teori-teori ini memiliki banyak perbedaan, mereka sama-sama memperhatikan perilaku dan sifat-sifat pribadi serta proses kognitif yang menghasilkan perilaku (Littlejohn dan Foss, 2009: 63).

Tradisi sosiopsikologis dibagi dalam tiga cabang besar: (1) perilaku; (2) kognitif; (3) biologis. Dalam sudut pandang perilaku, teori berkonsentrasi pada bagaimana manusia berperilaku dalam situasi-situasi komunikasi. Pendekatan kedua, yaitu teori kognitif yang berpusat pada bentuk pemikiran. Cabang ini berkonsentrasi pada bagaimana individu memperoleh, menyimpan, dan memproses informasi yang dapat menghasilkan suatu perilaku. Dengan kata lain, apa yang individu lakukan dalam situasi komunikasi bergantung tidak hanya pada bentuk stimulus-respons, melainkan pada kemampuan mental yang digunakan untuk mengolah informasi. Sedangkan cabang yang ketiga adalah biologis, dimana para ahli psikoligi dan teori perilaku mengasumsikan kajian genetic menjadi semakin penting. Mereka tertarik pada efek-efek fungsi dan struktur otak, neurochemistry dan faktor genetik dalam menjelaskan perilaku manusia. Para ahli percaya bahwa banyak dari sifat, cara berfikir, dan berperilaku individu diikat secara biologis dan didapat bukan hanya dari pembelajaran atau faktor-faktor situasi, melainkan dari pengaruh neurobiologis sejak lahir (Littlejohn, 2009: 65).

Belakangan, teori kaum behaviouris lebih dikenal dengan teori belajar, karena menurut mereka seluruh perilaku manusiakecuali insting adalah hasil belajar. Belajar artinya perubahan perilaku organisme sebagai perubahan lingkungan (Rakhmat 2007: 2021).

Menurut teori baru efek media massa yaitu social learning theory (teori belajar 
sosial) dari Bandura, orang cenderung meniru perilaku yang diamatinya. Stimulus menjadi teladan untuk perilakunya. Teori belajar sosial dapat diandalkan untuk menjelaskan efek bahavioural media massa (Ardianto dan Erdinaya, 2007: 56). Adanya teori ini bertujuan untuk memahami efek terpaan media (Ardianto dalam Erdinaya, 2007: 62).

Social cognitive theory provides an agentic conceptual framework within which to examine the determinants and mechanisms of such effects. Human behavior has often been explained in terms of undierectional causation, in which behavior has often been explained in terms of triadic reciprocal causation. In this transactional view of self and society personal factors in the form of cognitive affective, and biological events; behavioral patterns; and environmental events all operate as interacting determinants that influence each other bidirectionally (Bryant dan Zillmann, 2002: 121).

Dalam penelitian ini personal determinants berasal dari internal individu, yang dalam konteks ini berupa penggunaan media sosial facebook sebagai sarana menambah informasi dan pengetahuan akan ASI eksklusif. Teori kognitif sosial memberikan penekanan pada pentingnya karakteristik atau sifat manusia yang unik yang terdiri atas empat karakteristik atau sifat yaitu simbolisasi (symbolizing), pengaturan diri (self-regulatory), koreksi diri (selfreflective), dan kemampuan belajar (vicarious capacities). Kemampun belajar menjadi focus untuk menjelaskan variabel penggunaan media sosial, karena kemampuan belajar diartikan sebagai kemampuan untuk belajar dari sumber lain tanpa harus memiliki pengalaman secara langsung. Kemampuan ini biasanya mengacu pada penggunaan media massa, baik secara positif maupun negatif (Morissan, 2010: 245).
Environmental determinants berkaitan dengan variabel terpaan iklan layanan masyarakat "Ruang ASI", dukungan keluarga, dan dukungan lingkungan kerja. Sedangkan behaviour determinants dalam penelitian ini adalah perilaku atau keberhasilan ibu bekerja memberi ASI eksklusif.

Dalam dunia komunikasi, informasi diartikan oleh Shanon dan Weaver sebagai energi yang terpolakan, yang mempengaruhi individu dalam memgambil keputusan dari kemungkinan-kemungkinan pilihan yang ada. Shanon dan Weaver menyatakan bahwa informasi yang disampaikan memiliki tujuan untuk menambah pengetahuan, mengubah sikap, dan perilaku individu serta khalayak (Wiryanto, 2006: 16).Pemerintah melalui Kementrian Kesehatan RI berkehendak untuk berkomunikasi dengan masyarakat guna menyampaikan informasi atau pesan tentang ASI Eksklusif. Salah satu cara yang dipilih untuk menyampaikan pesan tentang ASI eksklusif adalah melalui Iklan Layanan Masyarakat.

Upaya penyebaran informasi yang dilakukan Kemenkes RI melalui iklan layanan masyarakat merupakan proses komunikasi massa. Defenisi komunikasi massa yang paling sederhana dikemukakan oleh Bittner yakni "komunikasi massa adalah pesan yang dikomunikasikan melalui media massa pada sejumlah orang besar". Sedangkan defenisi komunikasi massa yang lebih rinci dikemukakan oleh ahli komunikasi yakni Gerbner "komunikasi massa adalah produksi dan distribusi yang berlandaskan teknologi dan lembaga dari arus pesan yang kontiniu serta paling luas dimiliki orang dalam masyarakat industri (Ardianto, 2004: 4).

Littlejohn memaparkan bahwa komunikasi massa adalah sebuah proses dimana organisasi media menciptakan dan menyebarkan pesan-pesan pada masyarakat 
luas dan proses tersebut dicari, digunakan, dipahami, dan dipengaruhi oleh audiens (Littlejohn, 2009: 405). Salah satu model awal untuk menggambarkan pandangan ini adalah model yang digunakan oleh Harold Lasswell. Dalam artikel klasik tahun 1948 ini, Lasswell menghadirkan model komunikasi yang sederhana dan sering digunakan: siapa, mengatakan apa, di saluran mana, untuk siapa, dengan pengaruh apa (Edward Sapir dalam Littlejohn, 2009: 405). Dengan menggunakan model ini Lasswell menyusun bagian-bagian sistem komunikasi massa. Lasswell mampu mengidentifikasi fungsi-fungsi utama media komunikasi, termasuk pengamatan (surveillance), memberikan informasi tentang lingkungan; memberikan pilihan untuk memecahkan masalah, atau hubungan (correlation); dan sosialisasi serta pendidikan yang dikenal dengan transmisi (transmission).

Effendi (2000), media massa digunakan dalam komunikasi apabila komunikan berjumlah banyak dan bertempat tinggal jauh. Keuntungan komunikasi dengan menggunakan media massa adalah bahwa media massa menimbulkan keserempakan artinya suatu pesan dapat diterima oleh komunikan yang jumlahnya relatif banyak. Jadi untuk menyebarkan informasi, media massa sangat efektif dan dapat mengubah sikap, pendapat dan perilaku komunikan.

Salah satu media massa konvensional yang saat ini masih dianggap memiliki kekuatan yang besar untuk mempengaruhi masyarakat adalah televisi. Oleh karena itu pemerintah melalui Kementrian kesehatan RI memilih menggunakan media televisi untuk menyampaikan pesan tentang ASI eksklusif melalui iklan layanan masyarakat.

Iklan Layanan Masyarakat (selanjutnya disebut ILM) adalah iklan yang digunakan untuk menyampaikan informasi, mengajak, atau mendidik khalayak dimana tujuan akhirnya bukan untuk mendapatkan keuntungan ekonomi, melainkan keuntungan sosial. Keuntungan sosial yang dimaksud adalah munculnya penambahan pengetahuan, kesadaran sikap dan perubahan perilaku masyarakat terhadap masalah yang diiklankan serta mendapatkan citra baik dimasyarakat. Umumnya, materi pesan yang disampaikan dalam jenis iklan ini berupa informasiinformasi publik untuk menggugah khalayak melakukan sesuatu kebaikan yang normatif. Misalnya anjuran agar tertib berlalu lintas, memiliki budaya antri, hemat listrik, hemat air, hemat BBM, dan sebagainya (Widyatama, 2005: 104).

Iklan Layanan Masyarakat merupakan salah satu alat dalam pemasaran sosial (Social Marketing). Pemasaran sosial menggunakan prinsip dan teknik dari pemasaran komersil untuk mempengaruhi target audiens dengan secara sukarela menerima, menolak, memodifikasi, atau membebaskan perilaku untuk mendapatkan keuntungan pada individu tersebut, kelompok, atau masyarakat secara menyeluruh. Pemasaran sosial digunakan untuk mempengaruhi audiens untuk mengubah perilaku mereka demi kesehatan, mencegah luka-luka, melindungi lingkungan, atau berkontribusi pada komunitas. Pada pemasaran sosial hasil akhir bukan profit berupa uang yang akan didapat bagi si pemasar, tetapi keuntungan perubahan sikap, pengetahuan, dan perilaku demi hidup yang lebih baik sesuai tujuan pemasar kepada audiens (Kotler, Roberto, Lee, 2002: 5).

Proses komunikasi di dalam iklan dalam menjangkau khalayaknya terjadi jika dilakukan dalam jangka yang intens atau lama. Seperti halnya iklan layanan masyarakat tentang ASI eksklusif. Semakin sering iklan menerpa masyarakat semakin besar juga perhatian masyarakat akan iklan tersebut yang nantinya akan terbentuk awareness. Terpaan 
iklan (exposure to advertisement) adalah merupakan suatu proses dimana terjadi respon kognitif atau pemikiran ketika mereka membaca, melihat atau mendengar komunikasi tersebut (Belch, 1990, p.150). Menurut Jalaludin Rakhmat (1989), terpaan media (media exposure) dapat dioperasionalkan sebagai frekuensi individu dalam menonton televisi, film, membaca majalah atau surat kabar maupun mendengarkan radio.

Dalam ILM "Ruang ASI", produk yang ditawarkan yaitu supaya audiens terutama ibu bekerja tetap memberikan ASI Eksklusif walaupun bayi ditinggal bekerja, dengan cara memberikan ASI Perah, dimana sewaktu bekerja ibu bisa memompa atau memerah ASI dan disimpan dalam almari pendingin agar nantinya bisa diberikan pada bayi mereka. Ketika audiens berinteraksi dengan pesan melalui iklan inilah diartikan audiens sedang menerima terpaan (exposure) iklan (Shimp, 2000: 182). Jadi terpaan ILM "Ruang ASI" adalah audiens berinteraksi dengan pesan dari pemasar dengan melihat ILM "Ruang ASI" di televisi.

Penggunaan media sosial facebook merupakan variabel kedua yang diteliti pengaruhnya terhadap tingkat keberhasilan ibu bekerja memberi ASI eksklusif. Munculnya facebook sebagai salah satu media sosial diawali dari perkembangan media baru yang berbasis internet.

McQuail (2011: 156) mengidentifikasi lima kategori utama media baru yang samasama memiliki kesamaan saluran tertentu dan kurang lebih dibedakan berdasarkan jenis penggunaan, konten dan konteks. Media sosial termasuk dalam kategori media partisipasi kolektif (collective participatory media). Penggunaan internet sebagai ajang berbagi dan bertukar informasi, gagasan dan pengalaman, serta untuk mengembangkan hubungan pribadi yang aktif. Situs jejaring sosial (media sosial) termasuk di dalam kelompok ini.

Melalui media sosial, pengguna dapat menjalin persahabatan dan berbagi informasi dengan pengguna lainnya tanpa ada hambatan berupa jarak dan waktu. Media sosial menjadi media interaksi baru yang membuat ruangruang bagi masyarakat untuk saling berbagi, bercerita dan menyalurkan ide-idenya. Akibatnya, masyarakat melakukan migrasi virtual untuk berinteraksi di ruang maya/virtual agar dapat berinteraksi dengan pengguna lainnya. Jika sebelumnya, komunikasi dan interaksi kita hanya sebatas tatap muka, maka hal tersebut semakin terpanjangkan dengan hadirnya media social. Salah satunya melalui facebook.

Pemilihan facebook sebagai media untuk mencari informasi sekaligus bersosialisasi merupakan internalisasi dari teori Uses and Gratification. Teori Uses and Gratification menjelaskan kapan dan bagaimana audien sebagai konsumen media menjadi lebih aktif atau kurang aktif dalam menggunakan media dan akibat atau konsekuensinya dari penggunaan media itu.

Teori ini mengajukan gagasan bahwa perbedaan individu menyebabkan audien mencari, menggunakan dan memberikan tanggapan terhadap isi media secara berbedabeda, yang disebabkan oleh berbagai faktor social dan psikologis yang berbeda di antara individu. Teori ini tidak memberikan perhatian pada efek langsung media terhadap audien, tetapi memfokuskan perhatian pada motivasi dan perilaku audien terhadap media atau bagaimana dan mengapa mereka menggunakan atau mengkonsumsi media.Singkatnya, teori ini berupaya menjelaskan, what do people do with the media? (Klapper, 1963; Rubin, 1994 dalam Morissan, 2010). 
Terdapat lima asumsi dasar yang menjadi inti gagasan teori Uses and Gratification:

1) Audiens aktif dan berorientasi pada tujuan ketika menggunakan media.

2) Inisiatif untuk mendapatkan kepuasan media ditentukan audien

3) Media bersaing dengan sumber kepuasan lain

4) Audien sadar sepenuhnya terhadap ketertarikan, motif, dan penggunaan

media. Audien melakukan pilihan secara sadar terhadap media tertentu yang akan digunakannya.

5) Penilaian isi media ditentukan oleh audien.

Teori Uses and Gratification tidak dapat menjelaskan pengaruh penggunaan media terhadap perubahan perilaku. Oleh karena itu untuk menganalisis pengaruh penggunaan media sosial peneliti menggunakan DynamicSocial Impact Theory(DSIT) yang dikemukakan oleh Bibb Latane (1996). DSIT menggambarkan masyarakat sebagai sistem komunikasi besar yang terdiri dari sejumlah subsistem budaya, yang mencakup interaksi antar individu. Budaya adalah kelompok besar dimana individu-individu membagi ideologi dan praktik umum. DSIT mencoba menjelaskan bagaimana komunitas dan budaya terbentuk.

Individu cenderung bergabung dengan kelompok yang sepemikiran dengannya. Individu mengorganisasikan dirinya secara sibernetis ke dalam struktur dinamis kelompok dengan karakteristik yang sejenis. Ibu yang mendukung pemberian ASI eksklusif akan cenderung berinteraksi dan berkelompok dengan ibu yang memiliki pemikiran yang sama, mereka akan saling mempengaruhi satu sama lain dan akhirnya membentuk budaya di kalangan mereka
Individu-individu dengan ide, keyakinan, sikap, dan perilaku yang berbedabeda berinteraksi, berkomunikasi, dan saling mempengaruhi dalam social space. Aspekaspek yang berpengaruh dalam social space antara lain: jarak fisik, susunan sosial (ras, kelas), dan media komunikasi. Pengaruh antarindividu bervariasi sepanjang tiga dimensi: kekuatan (strength) individu dalam sosial space, imediasi (immediacy) yaitu ketertutupan di antara dua orang, dan jumlah orang yang ada di dalam social space. Semakin banyak individu yang terpengaruh dalam social space, semakin cenderung membentuk kelompok. Mekanisme sibernetika menjamin keberagaman dalam sistem yang lebih luas. Interaksi tidak pernah seluruhnya acak, dan pengaruh tidak pernah seluruhnya linear dalam sebuah sistem. Ini menjaga perubahan dan keberagaman sistem. Masyarakat sebagai sebuah sistem besar dari interaksi individu dimana terjadifeedback loops secara berkelanjutan membentuk tatanan sosial dan keberagaman (Erwin, 2015).

Dukungan keluarga merupakan variabel ketiga yang diteliti pengaruhnya terhadap tingkat keberhasilan ibu bekerja memberi ASI eksklusif.

Menurut Sarwono (2003) dukungan adalah suatu upaya yang diberikan kepada orang lain, baik moril maupun materil untuk memotivasi orang tersebut dalam melaksanakan kegiatan. Menurut Santoso (2001) dukungan yaitu suatu usaha untuk menyokong sesuatu atau suatu daya upaya untuk membawa sesuatu.

Bailon dan Maglaya dalam Sudiharto (2007) menyatakan, bahwa keluarga adalah dua atau lebih individu yang bergabung karena hubungan darah, perkawinan atau adopsi. Mereka hidup dalam satu rumah tangga, melakukan interaksi satu sama lain 
menurut peran masing-masing, serta menciptakan dan mempertahankan suatu budaya. Keluarga adalah suatu kelompok yang terdiri dari dua orang atau lebih yang di rekat oleh ikatan darah, perkawinan, atau adopsi serta tinggal bersama. Dukungan keluarga merupakan suatu proses yang terjadi sepanjang masa kehidupan, sifat dan jenis dukungan berbeda-beda pada setiap tahap siklus kehidupan (Friedman, 1998).

Baik keluarga inti maupun keluarga besar berfungsi sebagai sistem pendukung bagi anggotanya. Caplan (1976) dalam Friedman (1998) menjelaskan bahwa keluarga memiliki fungsi dukungan yaitu dukungan informasional, dukungan penilaian, dukungan isntrumental dan dukungan emosional. Dukungan informasional adalah keluarga berfungsi sebagai sebuah keluarga diseminator atau penyebar informasi tentang semua informasi yang ada dalam kehidupan. Keluarga berfungsi sebagai pencari informasi yang berhubungan dengan masalah menyusui dari tenagakesehatan, dan melakukan konsultasi, serta mencari informasi dari media cetak maupun sumber lain yang mendukung.

Dukungan penilaian adalah jenis dukungan dimana keluarga bertindak sebagai pembimbing dan bimbingan umpan balik, memecahkan masalah dan sebagai sumber validator identitas anggota dalam keluarga. Dukungan instrumental adalah bentuk dukungan dimana keluarga sebagai sebuah sumber petolongan praktis dan kongkrit untuk menyelesaikan masalah, dan dukungan emosional adalah bentuk dukungan dimana keluarga sebagai sebuah tempat pemulihan yang aman dan damai untuk beristirahat dan membantu secara psikologis untuk menstabilkan emosi dan mengendalikan diri. Salah satu bentuknya adalah melalui pemberian motivasi dan sebagai fasilitator serta mendengarkan seluruh keluhan-keluhan anggota keluarga atau ibu terhadap masalah yang sedang dihadapinya (Caplan dalam Friedman 1998).

Menurut Sudiharto (2007) dukungan keluarga mempunyai hubungan dengan suksesnya pemberian ASI Eksklusif kepada bayi. Dukungan keluarga adalah dukungan untuk memotivasi ibu memberikan ASI saja kepada bayinya sampai usia 6bulan, memberikan dukungan psikologis kepada ibu dan mempersiapkan nutrisi yang seimbang kepada ibu. Menurut Roesli (2007), suami dan keluarga dapat berperan aktif dalam pemberian ASI dengan cara memberikan dukungan emosional atau bantuan praktis lainnya.

Selain dukungan keluarga, lingkungan yang dapat mendukung keberhasilan ibu bekerja memberi ASI eksklusif tentunya adalah lingkungan kerja.

Di dalam Peraturan Pemerintah Nomor 33 tahun 2012 tentang Pemberian Air Susu Ibu Eksklusif pasal 30 disebutkan sebagai berikut:

1) Pengurus Tempat Kerja dan penyelenggara tempat sarana umum harus mendukung program ASI Eksklusif

2) Ketentuan mengenai dukungan program ASI Eksklusif di Tempat Kerja sebagaimana dimaksud pada ayat (1) dilaksanakan sesuai dengan peraturan perusahaan antara pengusaha dan pekerja/buruh, atau melalui perjanjian kerja bersama antara serikat pekerja/serikat buruh dengan pengusaha.

3) Pengurus Tempat Kerja dan penyelenggara tempat sarana umum harus menyediakan fasilitas khusus untuk menyusui dan/atau memerah ASI sesuai dengan kondisi perusahaan.

4) Ketentuan lebih lanjut mengenai tata cara penyediaan fasilitas khusus menyusui dan/atau memerah ASI sebagaimana 
dimaksud pada ayat (3) diatur dengan Peraturan Menteri.

Peraturan mengenai tata cara penyediaan fasilitas khusus menyusui dan/atau memerah ASI belum diterbitkan sampai dengan sekarang. Namun untuk persyaratan minimal sebuah pojok laktasi di tempat kerja adalah sebagai berikut: (setting up of Lactation Room, 2013)

1. Merupakan ruangan khusus untuk kepentingan laktasi

2. Memiliki sebuah pintu yang terkunci

3. Sebuah kursi yang nyaman dan dipastikan kaki ukuran wanita rata-rata dapat menyentuh lantai.

4. Stopkontak listrik untuk menghubungkan dengan pompa ASI

5. Sebuah meja untuk meletakkan pompa ASI, botol ASI dan perlengkapan lain yang terletak di sepan kursi.

6. Dapat dipastikan ruangan selalu bersih dan nyaman.

Selain fitur diatas, pojok laktasi juga bisa diberikan tambahan fasilitas sebagai berikut:

1. Sebuah wastafel terletak di dalam ruangan, lengkap dengan sabun serta handuk/tisu pengering tangan

2. Lemari es untuk menyimpan ASI

3. Cahaya yang cukup, gambar dan dekorasi yang mendorong relaksasi.

Secara ideal setiap tempat kerja yang mempekerjakan perempuan hendaknya memiliki tempat penitipan bayi atau anak, sehingga ibu dapat membawa bayinya ke tempat kerja dan menyusui setiap beberapa jam. Namun bila tidak memungkinkan karena tempat kerja jauh dari rumah, tidak memiliki kenderaan pribadi atau jemputan kantor, maka cara lain yang mudah adalah memberikan ASI perah (Roesli, 2007)

Terdapat tujuh langkah yang sangat penting untuk keberhasilan pemberian ASI secara esklsuif terumata bagi ibu bekerja, yaitu (1) mempersiapkan payudara, (2) mempelajari ASI dan tatalaksana menyusui, (3) menciptakan dukungan keluarga, (4) memilih tempat melahirkan yang sayang bayi, (5) memilih tenaga kesehatan yangmendukung pemberian ASI secara Eksklusif (6) mencari ahli persolan menyusui seperti klinik laksatasi untuk persiapan apabila mereka mengalami kesukaran, dan (7) menciptakan suatu sikap positif tentang ASI dan menyusui (Roesli, 2007).

\section{Metode Penelitian}

Penelitian ini menggunakan metode survai yang ingin mengetahui bagaimana pengaruh terpaan iklan layanan masyarakat, penggunaan media sosial facebook, dukungan keluarga, dan dukungan lingkungan kerja terhadap tingkat keberhasilan ibu bekerja memberi ASI eksklusif. Hipotesis minor dalam penelitian ini adalah:

1. Terdapat pengaruh positif antara terpaan iklan layanan masyarakat terhadap tingkat keberhasilan ibu bekerja memberi ASI eksklusif.

2. Terdapat pengaruh positif antara penggunaan media sosial facebook terhadap tingkat keberhasian ibu bekerja memberi ASI eksklusif.

3. Terdapat pengaruh positif antara dukungan keluarga terhadap keberhasilan ibu bekerja dalam memberi ASI Eksklusif.

4. Terdapat pengaruh positif antara dukungan tempat kerja terhadap keberhasilan ibu bekerja dalam memberi ASI Eksklusif. 


\section{Visualisasi Konsep}

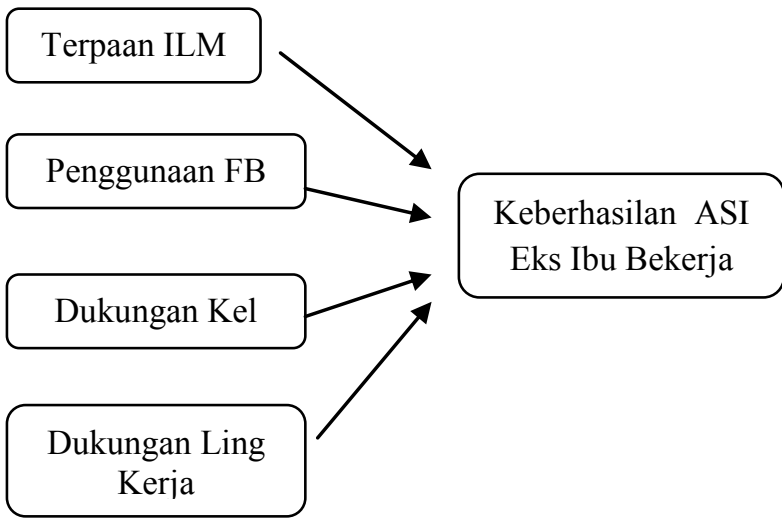

\section{Hasil Penelitian}

Berdasarkan hasil wawancara yang telah dilakukan pada 100 ibu bekerja yang tinggal di kota Semarang dan memiliki bayi berusia 6 bulan keatas, diperoleh hasil masing-masing hipotesis minor diterima:

1) Nilai t-hitung untuk variabel terpaan iklan layanan masyarakat (X1) sebesar 2,060dengan probabilitas kesalahan (sig) sebesar 0,042. Oleh karena sig sebesar $0,042<0,05$, maka inferensi yang diambil ialah secara partial variabel terpaan iklan layanan masyarakat (X1) berpengaruh positif terhadap variabel tingkat keberhasilan ibu bekerja dalam memberikan ASI Eksklusif(Y). Temuan ini sejalan dengan penyataan Terrence A. Shimp bahwa exposure (terpaan iklan) merupakan tahap awal yang penting menuju tahap-tahap selanjutnya dari proses informasi, fakta yang ada alah mengekspos konsumen kepada pesan komunikator pemasaran tidak menjamin bahwa pesan akan memberikan pengaruh. Memperoleh exposure adalah suatu keharusan, namun tidak cukup untuk mencapai keberhailan komunikasi. Mengekspos konsumen kepada pesan suatu merek merupakan fungsi dari keputusan managerial utama mengenai besarnya anggaran serta pilihan media dan alat menyampaikan pesan tersebut. Dengan kata lain, persentase dari khalayak sasaran tinggi akan diekspo kepada suatu pesan merek jika dialokasikan anggaran yang mencukupi serta pilihan media yang tepat; anggara yang tidak cukup atau pilihan media yang buruk akan menghasilkan level of exposure yang rendah (Shimp, 2003: 182).

Jika dikaitkan dengan efek media massa, maka hasil penelitian ini menunjukkan adanya efek kognitif, afektif , dan behavioral yang disebabkan oleh iklan layanan masyarakat (Rakhmat. 2007: 219). Sejumlah responden mengaku pengetahuannya bertambah setelah diterpa iklan, keyakinan akan memberi ASI esklusif juga meningkat, dan akhirnya memiliki perilaku yang mendukung ASI eksklusif. Namun pengaruh iklan layanan masyarakat bukanlah yang paling besar terhadap tingkat keberhasilan ibu bekerja memberi ASI eksklusif, justru ILM berpengaruh paling kecil diantara tiga variabel lainnya yaitu 0,183 atau 18,3 persen.

2) Nilai t-hitung untuk variabel penggunaan media sosial facebook (X2) sebesar 3,327dengan probabilitas kesalahan (sig) sebesar 0,001. Oleh karena sig sebesar $0,001<0,05$, maka inferensi yang diambil ialah secara partial variabel penggunaan media sosial facebook (X2) berpengaruh positif terhadap variabel tingkat keberhasilan ibu bekerja dalam memberikan ASI Eksklusif(Y).

Temuan ini menggambarkan bahwa individu yang memilih menggunakan facebook sebagai media untuk memenuhi kebutuhan informasi dan memenuhi kepuasan, mampu mempengaruhi perilaku dan tingkat keberhasilan ibu bekerja 
dalam memberi ASI eksklusif. Pengguna aktif dalam mencari informasi dari facebook dan memanfaatkan facebook untuk berteman dengan komunitas pendukung ASI eksklusif. Jadi selain memperileh tambahan informasi, pengguna facebook juga bersosialisasi, saling mendukung dan saling mempengaruhi untuk tercapainya keberhasilan dalam memberikan ASI eksklusif dan ASI sampai 2 tahun. Fenomena tersebut sesuai dengan Dynamic Social Impact Theory.

Variabel penggunaan media sosial facebook memiliki pengaruh sebesar 0,26 atau 26 persen, yaitu di urutan kedua setelah variabel dukungan keluarga.

3) Nilai t-hitung untuk variabel dukungan keluarga (X3) sebesar 6,762dengan probabilitas kesalahan (sig) sebesar 0,000. Oleh karena sig sebesar $0,000<0,05$, maka inferensi yang diambil ialah secara partial variabel dukungan keluarga (X3) berpengaruh positif terhadap variabel tingkat keberhasilan ibu bekerja dalam memberikan ASI Eksklusif(Y).

Temuan ini memperkuat pernyataan Caplan bahwa keluarga baik kekuarga inti maupun keluarga besar berfungi sebagai sistem pendukung. Bahwa keluarga memiliki fungsi dukungan, yaitu dukungan informasional (membantu memberi informasi tentang pentingnya ASI eksklusif kepada ibu), dukungan penilaian (memberi masukan atau solusi positif apabila ibu menghadapi kendala menyusui), dukungan instrumental (membantu menyiapkan fasilitas untuk memerah ASI dan menyimpan ASI perah), dan dukungan emosional (menciptakan rasa nyaman kepada ibu menyusui, dan tidak menyampaikan hal-hal yang dapat mematahkan semangat ibu menyusui). Semakin besar dukungan keluarga yang diberikan kepada ibu bekerja, akan semakin besar pula tingkat keberhasilan ibu bekerja untuk memberi ASI eksklusif. Berdasarkan perhitungan regresi, pengaruh dukungan keuarga nilainya paling besar diantara ketiga varibel lainnya yaitu 0,46 atau 46 persen. Jadi semakin tinggi dukungan keluarga akan semakin tinggi pula tingkat keberhasilan ibu bekerja memberi ASI eksklusif.

4) Nilai t-hitung untuk variabel dukungan lingkungan kerja (X4) sebesar 3,266dengan probabilitas kesalahan (sig) sebesar 0,002. Oleh karena sig sebesar $0,002<0,05$, maka inferensi yang diambil ialah secara partial variabel dukungan lingkungan kerja (X4) berpengaruh positif terhadap variabel tingkat keberhasilan ibu bekerja dalam memberikan ASI Eksklusif(Y).

Temuan ini sejalan dengan teori dukungan sosial yang dapat mempengaruhi perilaku kesehatan. Dukungan sosial mengacu pada memberikan kenyamanan, peduli, penghargaan, dan bantuan untuk seseorang dari olang lain atau kelompok (Uchino dalam Safarino, 2011). Sedangkan menurut Heaney dan Israel (2008) yang bisa memberikan dukungan sosial adalah: (1) Informal network, seperti keluarga, teman, rekan kerja dan atasan; (2) Formal network, seperti petugas kesehatan dan human service workers.

Dukungan sosial dpat mempengaruhi frekuensi dan durasi paparan stress. Seorang atasan yang mendukung dalam program pemberian ASI eksklusif di tempat bekerja akan meningkatkan kepercayaan diri seorang ibu untuk bisa 
memberikan ASI eksklusif, sehingga resiko kegagalan dapat berkurang.

Variabel dukungan lingkungan kerja berpengaruh sebesar 0,204 atau 20,4 persen menempati urutan ketiga setelah penggunaan media sosial facebook.

\section{Penutup}

\section{Simpulan}

Secara keseluruhan dengan hipotesis mayor yang diajukan, penelitian ini berhasil menjawab tujuan penelitian. Dalam penelitian ini terpaan iklan layanan masyarakat versi "Ruang ASI", penggunaan media sosial facebook, dukungan keluarga, dukungan lingkungan kerja mempunya pengaruh terhadap tingkat keberhasilan ibu bekerja memberi ASI eksklusif dengan nilai koefisien determinasi sebesar 70,2\%. Dengan demikian 29,8\% merupakan nilai sisa yang menujukkan adanya variabel-variabel lain yang dapat mempengaruhi tingkat keberhasilan ibu bekerja memberi ASI eksklusif. Temuan ini sejalan dengan teori Social Learning, dimana behaviour determinants (perilaku ibu menyusui) dipengaruhi oleh personal determinant(penggunaan media sosial facebook), danenvirontment determinant (terpaan ILM, dukungan keluarga, dukungan lingkungan kerja).

\section{Saran}

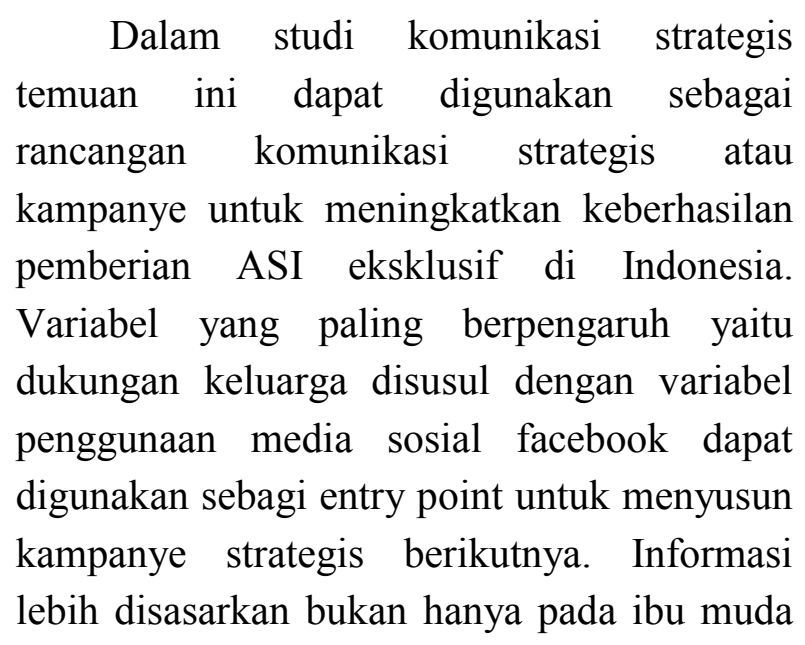

atau calon ibu, tapi justru pada keluarga, dan media sosial facebook dapat dipilih sebagi media kampanye oleh institusi pemerintah.

\section{Daftar Pustaka}

Ardianto, Elvinaro \& Lukiati Komala Erdinaya. (2007). Komunikasi Massa. Bandung: Simbiosa Rekatama Media

Bandura, Albert. (1977). Social Learning Theory. Prentice Hall: New Jersey

Belch, E. George den Belch, A. Michael. (2012). Advertising and Promotion, and Marketing Communications, Fourth Edition. United Stage: Person Educate Inc. Bobak. (2005). Buku Ajar Keperawatan Maternitas edisi 4. Jakarta: EGC.

Ghozali, Imam. (2006). Aplikasi Analisis Multivariate dengan Program SPSS, Semarang: Badan Penerbit Universitas Diponegoro.

Jefkins, Frank. (1997). Periklanan Edisi 3. Jakarta:PenerbitErlangga

Jennings, Bryant and Dolf Zillmann. (2002).

Media effects advantaced in theory and research, $2^{\text {nd }}$ edition. New Jersey: Lawrence Erbaum Associates.

Kottler, Roberto \& Lee. (2002). Social Marketing. New Jersey: United States of America-SAGE Publications.

Kriyantono, R. (2006). Teknik Praktis Riset Komunikasi. Jakarta: PT. KencanaPrenada Media Group.

Littlejohn, Stephen W. (2009). Teori

Komunikasi "Theories of Human

Communication" edisi 9. Jakarta: Salemba Humanika.

McQuail, Denis. (2011). Teori Komunikasi

Massa McQuail. Jakarta: Salemba Humanika.

Morissan, (2010). Teori KomunikasiMassa. Jakarta: GhaliaIndonesia. 
Morissan. (2010). Periklanan: Komunikasi Pemasaran Terpadu. Jakarta: Prenada Media Group.

Mowen, Jhon C, Minor Michael. (2002). Perilaku Konsumen Jilid 1, edisikelima. Jakarta: Erlangga

Notoatmodjo, Soekidjo. (2003). Pendidikandan Perilaku Kesehatan. Jakarta: RinekaCipta.

Pusdatin, Kementrian Kesehatan Republik Indonesia. (2012). Infodatin, Situasi dan Analisis ASI Eksklusif. Jakarta: Kementrian Kesehatan Republik Indonesia.

Rakhmat, Jalaluddin. (2004). Psikologi Komunikasi. Bandung: PT. Remaja Rosdakarya.

Rakhmat, Jalaluddin. (2007). Metode Penelitian Komunikasi. Bandung: PT. RemajaRosdakarya.
Santoso, Singgih. (2000). SPSSMengolah Data Secara Profesional, Jakarta: PT. Elex Media Koinputindo.

Shimp, Terence A. (2000). Advertising Promotion and Supplement Aspect of Integrated Marketing Communication 5th Edition; Alih Bahasa: Periklanan Promosi dan Aspek Tambahan Komunikasi Pemasaran Terpadu, edisi ke-5, Terjemahan: Reyvani Syahrial. Jakarta: Erlangga

Singarimbun, Masri. (2008). Metode Penelitian Survei. Jakarta: LP3ES.

Widyatama, Rendra. (2009. Buku Pengantar Periklanan, Cetakan 6. Yogyakarta: Pustaka Book Publisher.

Wiryanto. (2006). Teori Komunikasi Massa. Jakarta: PT. Grasindo. 